\title{
Peran Organisasi Kepemudaan Ikatan Mahasiswa Muhammadiyah dalam Melaksanakan Pendidikan Politik Bagi Pemuda di Kota Padang
}

\author{
Adina Sukmawati, Al Rafni \\ Prodi Pendidikan Pancasila dan Kewarganegaraan \\ Universitas Negeri Padang \\ E-mail: adinasukmawati@gmail.com
}

\section{ABSTRAK}

Tujuan dari penelitian ini adalah mendeskripsikan peran organisasi kepemudaan Ikatan Mahasiswa Muhammadiya dalam melaksanakan pendidikan politik bagi pemuda dan mendeskripsikan hambatan dalam melaksanakan pendidikan politik yang di lakukan Ikatan Mahasiswa Muhammadiyah di Kota Padang. Metode penelitian dilakukan melalui pendekatan kualitatif deskriptif dengan menggunakan data primer dan sekunder. Informan penelitian adalah ketua pimpinan cabang IMM Kota Padang, ketua bidang hikmah, kabit bidang hikmah IMM Kota Padang. Teknik pengumpulan data pada penelitian ini menggunakan wawancara, observasi dan studi dokumentasi. Uji keabsahan data menggunakan teknik trianggulasi data.Teknik analisis data melalui tiga alur kegiatan yaitu reduksi data, penyajian data dan penarikan kesimpulan. Hasil dari penelitian menunjukkan bahwa terdapat tiga peran organisasi kepemudaan IMM di kota Padang, yakni yang pertama membantu pemerintah daerah dan mensosialisasikan politik khususnya mengenai isu-isu krusial. Kedua melakukan pelatihan edukasi politik terhadap kader IMM. Ketiga mendukung dalam kontribusi pemikiran dan membranding kader IMM untuk maju dalam internal kampus. Hambatan yang terdapat dalam melaksanakan pendidikan politik yaitu pertama keterbatasan anggaran, kedua keterbatasan narasumber, dan ketiga keterbatasan pengelola.

Kata Kunci: peran, pendidikan politik, Ikatan Mahasiswa Muhammadiyah

\section{ABSTRACT}

The purpose of this study is to describe the role of the Muhammadiya Student Association youth organization in carrying out political education for youth and describe the obstacles in carrying out political education by the Muhammadiyah Student Association in Padang. The research method was carried out through a descriptive qualitative approach using primary and secondary data. The research information was the head of the Padang branch of IMM, the head of wisdom, the head of Padang's IMM wisdom. The data collection techniques in this study used interviews, observation and documentation studies. The validity of the data uses data triangulation techniques. Data analysis techniques are done through three activities, namely data reduction, data presentation and drawing conclusions. The results of the study show that there are three roles of the IMM youth organization in the city 
of Padang, namely the first to help local governments and to socialize politics, especially on crucial issues. The second is political education training for IMM cadres. And the third supports the contribution of thinking and comparing IMM cadres to advance in the internal campus. And the obstacles that exist in carrying out political education are the first limited budget, second limitation of resource persons, and thirdly the limitations of managers.

Keywords: role, political education, Muhammadiyah Student Association

\section{PENDAHULUAN}

Pendidikan politik merupakan suatu proses yang mengajarkan kepada warga Negara mengenai nilainilai, norma-norma, serta simbolsimbol politik melalui media berupa sekolah, pemerintah, organisasi kemasyarakatan, dan partai politik. Proses pendidikan politik dapat dilakukan melalui kegiatan kursus, latihan kepemimpinan, seminar dan diskusi, serta keikutsertaan dalam forum pertemuan. Selain itu pendidikan politik juga diperlukan untuk menunjukan bagaimana cara berpolitik yang sehat dan bersaing secara sehat. Materi yang disampaiakan dalam proses pendidikan politik kepada masyarakat meliputi posisi, hak, kewajiban dan tanggung jawab setiap warga Negara dalam kehidupan berbangsa dan bernegara dan konstitusi Negara.

Pentingnya pendidikan politik pada masa saat ini sangat menetukan tingginya tingkat kesadaran politik seseorang. Semakin awal seorang individu mendapat pembelajaran tentang politik maka semakin tinggi kesadaran untuk mau berpartisipasi langsung dan mampu untuk mengemban tanggung jawab sebagai warga Negara yang baik. Pendidikan politik yang dapat di lihat dari peran suatu organisasi kepemudaan, yang mana organisasi kepemudaan ini merupakan salah satu mitra dari pemerintah di setiap daerah. Salah satu organisasi kepemudaan yang diteliti adalah ikatan mahasiswa muhammadiyah atau sering di kenal dengan singkatan IMM. IMM adalah sebuah organisasi gerakan mahasiswa islam, sekaligus organisasi otonom muhammadiyah yang bergerak di bidang keagamaan, kemahasiswaan, dan kemasyarakatan. Dalam hal ini ada peran yang di lakukan oleh sebuah organisasi kepemudaan khususnya IMM dalam melakukan pendidikan politik yang terdapat dalam kajian program kerja nya.

Penelitan terdahulu dilakukan oleh Erawati (2017) yang menunjukkan bahwa peran pendidikan politik di SMA Muhammadiyah 2 Surabaya yaitu menampung aspirasi peserta didik, inovasi dalam menarik masa untuk aktif, dan peran IPM sesuai misi sekolah dalam meningkatkan kemampuan berorganisasi dan leadership. Penelitan lain oleh Tanzil (2015) menunjukkan bahwa partisipasi Pemuda Pancasila dalam membantu Pemerintah dalam menjaga stabilitas sosial, diwujudkan dalam berbagai 
bentuk kegiatan seperti, keterlibatan dalam membantu aparat menjaga keamanan masyarakat, penanggulangan bencana alam seperti banjir, bencana kebakaran, pemberantasan dan penyalahgunaan narkoba dan lain-lain. Partisipasi Pemuda Pancasila dalam membantu Pemerintah menjaga stabilitas sosial belum berjalan maksimal. Kemudian Affandi (2015) menemukan bahwa Pendidikan politik dilaksanakan dengan cara melalui tahapan-tahapan, sosialisasi pendidikan politik generasi muda, sosialisasi bantuan politik, sosialisasi pemilu dan melalui website, media sosial, dan banner-banner. Sikap pelaksana masih cenderung hanya sebagai tugas dan fungsi dalam melaksanakan.

Koordinasi antar instansi sudah berjalan, namun belum optimal. Sehingga perlunya kreativitas pelaksana dengan berkolaborasi dengan instansi pendidikan. Pelaksanaan pendidikan politik di Bakesbangpol sudah sesuai dengan Peraturan walikota 62 tahun 2012 tentang tugas pokok dan fungsi Bakesbangpol yang tercantum di program. Pelaksanaan pendidikan poltik dilaksanakan setiap satu tahun, melibatkan berbagi elemen masyarakat dan generasi muda. Namun pendidikan politik yang dilaksanakan belum mampu memberikan pengaruh terhadap peningkatan partisipasi generasi muda di Kota Malang. Sehingga perlu adanya tindak lanjut terkait pengawalan dan pengawasan generasi muda setelah sosialisasi.

Sementara Perbedaan penelitian terdahulu dengan penelitian ini yaitu penelitian terdahulu membahas mengenai bagaimana peran yang di lakukan suatu organisasi kepemudaan dalam menjalankan kewajiban nya sebagai organisasi-organisasi tersebut yang mengarah kepada cara kerja, partisispasi, dan metode yang di gunakan. Sedangkan penelitian ini memfokuskan kepada peran organisasi kepemudaan IMM dalam melaksanakan pendidikan politik bagi pemuda di kota Padang.

Berdasarkan uraian di atas maka permasalahan penelitian ini adalah bagaimana Peran Organisasi Kepemudaan dalam Pendidikan Politik kajian Ikatan Mahasiswa Muhammadiyah Kota Padang. Tujuan dari penelitian ini adalah untuk mendeskripsikan peran IMM dalam melakukan pendidikan politik melalui program kerja. Bahwa Ikatan Mahasiswa Muhammadiyah (IMM) sabagai bagian dari Angkatan Muda Muhammadiyah (AMM) memiliki posisi yang strategis dalam rangka membanguan tradisi pembaharuan Muhammadiyah. Dengan basis kekuatan yang berada di kampuskampus Perguruan Tinggi Muhammadiyah (PTM), Perguruan Tinggi Negri (PTN) dan Perguruan Tinggi Swasta (PTS) lainnya, menjadikan IMM sebagai organisasi otonom (Ortom) Muhammadiyah yang di harapkan dapat memenuhi kebutuhan kader-kader akademis Muhammadiyah masa depan. Posisi ini meniscayakan IMM untuk selalu melakukan reorientasi dan menajemen visi, misi, peran, agenda, strategi, metode serta teknik gerakan. Dalam arti lain, IMM perlu melalukan penguatan gerakan, baik dari segi landasan pemikiran maupun program aksinya. Lalu dapat di khususkan 
untuk penelitian ini terdapat dalam program kerja IMM yang penyinggung pendidikan politik yaitu program kerja dalam bidang hikmah, politik, dan kebijakan publik.

\section{METODE PENELITIAN}

Penelitian ini menggunakan metode kualitatif. Pendekatan kualitatif yang digunakan untuk menganalisis data dan memahami peran organisasi kepemudaan dalam pendidikan politik kajian IMM kota Padang. Lokasi penelitian ini adalah Sekretariat Ikatan Mahasiswa Muhammadiyah Kota Padang. Informan pada penelitian ini menggunakan teknik purposive sampling/ sampel bertujuan. Dengan informan kunci ketua IMM kota Padang, ketua bidang hikmah, politik, dan kebijakan public, dan kader IMM kota Padang. Teknik pengumpulan data penggunakan metode observasi, wawancara, dan dokumentasi. Penyajian data dilakukan untuk mengemukakan hasil dari informasi dan data yang telah direduksi sehingga tersusun sesuai dengan kerangka berfikir dalam penelitian yang telah dirancang. Pada pendekatan kualitatif, penyajian data berupa teks naratif dengan mendeskripsikan hasil dari informasi sesuai fokus penelitian tentang peran IMM dalam melakukan pendidikan politik melalui program kerja.Penarikan kesimpulan dan verifikasi, Kesimpulan dianggap final ketika pengumpulan data berakhir dengan bergantung pada besarnya kumpulan-kumpulan catatan lapangan, pengkodeannya, penyimpanan dan metode pencarian ulang yang digunakan, serta kecakapan peneliti. Kesimpulankesimpulan juga diverifikasi selama kegiatan

(Suprayogo,2001:1950).

berlangsung

\section{HASIL DAN PEMBAHASAN}

Kartaprawira

(1988:54)

mengartikan pendidikan politik sebagai upaya untuk meningkatkan pengetahuan politik rakyat dan agar mereka dapat berpartisipasi secara maksimal dalam system politiknya. Selain itu pendidikan politik bertujuan untuk meningkatkan pengetahuan politik rakyat dan agar mereka dapat berpartisipasi secara maksimal dalam system politiknya. Sehingga pendidikan politik perlu dilaksanakan secara berkesinambungan agar masyarakat terus meningkatkan pemehamannya terhadap dunia politik yang selalu mengalami perkembangan. Definisi pendidikan politik ini mengandung tiga unsur penting, yakni: pertama, adanya perbuatan memberikan latihan, ajaran, serta bimbingan untuk mengembangkan kapasitas dan potensi diri manusia. Kedua, perbuatan dimaksud harus melalui proses dialogis yang harus di lakukan dengan suka rela antara pemberi dan penerima pesan secara rutin. Ketiga, perbuatan tersebut ditujukan untuk para penerima pesan dapat memiliki kesadaran akan pentingnya pendidikan politik.

Kartono (1990) memberikan pendapatnya tentang hubungan antara pendidikan dengan politik yaitu pendidikan dilihat sebagai faktor politik dan kekuatan politik. Sebab, pendidikan dan mahasiswa pada hakekatnya juga merupakan pencerminan dari kekuatan-kekuatan sosial-politik yang tengah berkuasa, dan merupakan refleksi dari orde penguasa yang ada. Menurut Biddle 
Volume 3 No. 22020

dan Thomas (dalam Hakim, 2001;18), peran adalah serangkaian rumusan yang membatasi perilaku-perilaku yang diharapkan dari pemegang kedudukan tertentu. Menurut Utami, teori peran (role theory) adalah teori yang merupakan perpaduan antara teori, orientasi, maupun disiplin ilmu. Istilah "peran" diambil dari dunia teater. Dalam teater, seorang aktor harus bermain sebagai seorang tokoh tertentu dan dalam posisinya sebagai tokoh itu ia diharapkan untuk berperilaku sesuai dengan tokoh. Posisi aktor dalam teater (sandiwara) itu kemudian dianalogikan dengan posisi seseorang dalam masyarakat. Sebagaimana halnya dalam teater, posisi orang dalam masyarakat sama dengan posisi aktor dalam teater, yaitu bahwa perilaku yang diharapkan daripadanya tidak berdiri sendiri, melainkan selalu berada dalam kaitan dengan adanya orang-orang lain yang berhubungan dengan orang atau aktor tersebut. Dari sudut pandang inilah disusun teori-teori peran.

Kahn et al mengenalkan teori peran pada literatur perilaku organisasi. Mereka menyatakan bahwa sebuah lingkungan organisasi dapat mempengaruhi harapan setiap individu mengenai perilaku peran mereka. Harapan tersebut meliputi norma-norma atau tekanan untuk bertindak dalam cara tertentu. Individu akan menerima pesan tersebut, menginterpretasikannya, dan merespon dalam berbagai cara. Masalah akan muncul ketika pesan yang dikirim tersebut tidak jelas, tidak secara langsung, tidak dapat diinterpretasikan dengan mudah, dan tidak sesuai dengan daya tangkap si penerima pesan. Akibatnya, pesan tersebut dinilai ambigu atau mengandung unsur konflik. Ketika hal itu terjadi, individu akan merespon pesan tersebut dengan cara yang tidak diharapkan oleh si pengirim pesan. Berdasarkan penjelasan diatas diketahui bahwa peran itu sangat penting yang mana diartikan peran adalah sesuatu yang diharapkan oleh individu dari seseorang yang memiliki status tertentu. Agar berjalan semestinya maka peran yang dilakukan haruslah sesuai dan pesan yang disampaikan harus sampai kepada individu tersebut. Pentingnya peran adalah karena ia mengatur perilaku seseorang. Peran menyebabkan seseorang pada batasbatas tertentu dapat meramalkan perbuatan-perbuatan orang lain. Orang yang bersangkutan akan menyesuaikan perilaku sendiri dengan perilaku orang-orang sekelompoknya. Hubungan-hubungan sosial yang ada dalam masyarakat merupakan hubungan antara peran-peran individu dalam masyarakat. Apabila seseorang melaksanakan hak dan kewajibannya maka ia menjalankan suatu peran. Hak adalah suatu peran yang beersifat fakultatif artinya boleh dilaksanakan atau tidak dilaksanakan, kewajiban bersifat interatif artinya harus dilaksanakan.

Organisasi secara umum adalah kelompok kerjasama antara pribadi yang diadakan untuk mencapai tujuan bersama yang telah ditentukan lebih dahulu. Organisasi dalam hal ini dimaksudkan sebagai satuan atau kelompok kerjasama para kader yang dibentuk dalam usaha untuk mencapai tujuan bersama. Adapun peran, tanggung jawab, dan hak pemuda terdapat dalam BAB V Pasal 16 sampai 21. Yaitu pemuda berperan aktif sebagai kekuatan moral, kontrol sosial, 
dan agen perubahan dalam segala aspek pembangunan nasional. IMM merupakan organisasi pergerakan Islam yang bergerak dikalangan mahasiswa, yang mempunyai tujuan menciptakan kader-kader yang matang bagi perkaderan Muhammadiyah. Di dalam IMM terdapat tiga ideologi, yaitu religiusitas, intelektualitas, dan humanitas. Ketiga ideologi tersebut selalu ditekankan kepada kader-kader IMM agar di dalam menciptakan kader Muhammadiyah dapat benar-benar matang dan mampu untuk meneruskan jalannya roda organisasi.

\begin{tabular}{llrr}
\multicolumn{1}{c}{ IMM } & adalah & salah & satu \\
organisasi & kader & yang akan \\
meneruskan & & perjuangan
\end{tabular} Muhammadiyah sebagai gerakan tajdid. Biasanya sebuah organisasi tentunya memerlukan kader-kader muda sebagai penerus tongkat estafet perjuangan. Demikian pula Muhammadiyah yang menasbihkan sebagai gerakan tajdid di Indonesia, mau tidak mau harus membina kaderkader muda untuk melajutkan roda organisasi kedepan. IMM sebagai bagain dari Angkatan Muada Muhammadiyah (AMM), memiliki posisi yang strategis dalam rangka membangun tradisi pembaharuan Muhammadiyah. Dengan basis kekuatan yang berada di kampuskampus Perguruan Tinggi Muhammadiyah (PTM), Perguruan Tinggi Negri (PTN) dan Perguruan Tinggi Swasta (PTS) lainnya, menjadikan IMM sebagai organisasi otonom Muhammadiyah yang diharapkan dapat memenuhi kebutuhan kader-kader akademis Muhammadiyah masa depan. Posisi ini meniscayakan IMM untuk selalu melakukan reorientasi dan menajemen visi, misi, peran, agenda, strategi, metode serta teknik gerakan. Dalam arti lain, IMM perlu melalukan penguatan gerakan, baik dari segi landasan pemikiran maupun program aksinya. Peran organisasi kepemudaan IMM dalam melaksanakan pendidikan politik terdiri dari tiga hal yaitu:

a. Membantu pemerintah daerah dan mensosialisasikan politik khususnya mengenai isu-isu krusial.

Dalam hal ini peran organisasi kepemudaan yaitu sebagai kekuatan moral, social control, dan agen perubahan yang terdapat dalam Undang-Undang Nomor 40 Tahun 2009, berhubungan dengan peran yang dilakukan organisasi IMM yaitu terdapat dalam program kerja bidang hikmah, politik, dan kebijakan publik. Dalam hasil wawancara, IMM membantu pemerintah daerah dengan cara mensosialisasikan politik. Ketua bidang hikmah menyatakan bahwa pada periode yang dia jalankan telah melakukan suatu program kerja dalam bidang hikmah, politik, dan kebijakan publik yang dilakukan dengan cara mengadakan diskusi-diskusi ringan mengenai isu-isu krusial yang terjadi di kota Padang. Dalam diskusi tersebut mereka mendatangkan para seniorsenior yang lebih berpengalaman dalam mendiskusikan isu-isu tersebut. Lalu mengadakan seminar regional yang mengangkat isu-isu politik yang terjadi, yang mana sebelum nya para kader IMM telah mengadakan kajian strategis. Seminar ini mendatangkan pemateri yang paham tentang nilai radikalisme yang bertujuan untuk memecahkan masalah yang terjadi.

b. Melakukan pelatihan edukasi politik terhadap kader IMM. 
Dalam melakukan pelatihan edukasi politik, disinggung sedikit mengenai apa itu edukasi politik atau pendidikan politik. Pendidikan politik merupakan suatu proses yang mengajarkan kepada warga Negara mengenai nilai-nilai, norma-norma, serta simbol-simbol politik melalui media berupa sekolah, pemerintah, organisasi kemasyarakatan, dan partai politik. Proses pendidikan politik dapat dilakukan melalui kegiatan kursus, latihan kepemimpinan, seminar dan diskusi, serta keikutsertaan dalam forum pertemuan. Dalam organisasi IMM ini, peran yang dilakukan yaitu dengan latihan kepemimpinan.

Dalam pelatihan edukasi politik, yang telah diadakan pada periode sebelumnya IMM kota Padang mengadakan acara latihan instruktur dasar. Acara tersebut dibuat untuk kader-kader IMM yang baru bergabung untuk menanamkan pendidikan politik kepada mereka. Acara diadakan dalam bentuk FGD, dialog, ataupun ceramah dan disesuaikan dengan jenis materi yang disampaikan. Kemudian terdapat kegiatan mingguan yang biasa dilakukan oleh bidang hikmah, politik, dan kebijakan publik yang bernama tantiren. Kegiatan tersebut sama dengan kegiatan diskusi kader untuk membahas keadaan IMM sekarang. Kegiatan ini biasanya dilakukan perfakultas, seperti di UMSB ada tiga fakultas, di UNP ada satu fakutas, UNAND satu fakultas, dan UIN di setiap fakultas ada. Masing-masing fakultas akan mengadakan setiap minggu. Dalam bidang hikmah, politik, dan kebijakan publik program yang dilakukun ada dua jenis yaitu program yang memiliki jangka waktu dan program yang tidak memiliki jangka waktu dalam menjalankan program kerjanya. Ini terdapat dalam progam edukasi politik yang di lakukan IMM dalam bidang hikmah, politik, dan kebijakan publik.

c. Mendukung dalam kontribusi pemikiran dan kontribusi dalam membranding kader IMM untuk maju dalam internal kampus.

Peran IMM dalam bidang hikmah yaitu seperti mendukung masing-masing kader nya untuk maju di internal kampus. Seperti ingin menjadi gubernur BEM di kampus dengan cara mendukung dalam kontribusi pemikiran dan kontribusi dalam membrending kader. Berdasarkan pernyataan tersebut membuktikan bahwa IMM memberikan kontribusi kepada kader IMM untuk maju dalam internal kampus.

Hambatan-hambatan yang ditemui dalam
melaksanakan peran IMM untuk
melakukan pendidikan politik a. Keterbatasan anggaran

Keterbatasan anggaran lazim menjadi hambatan-hambatan bagi suatu organisasi ketika menjalankan suatu program kerja. Kendala ini dapat menyebabkan tidak terlaksananya suatu program kerja atau peran yang mereka lakukan tersebut. Sejalan dengan pendapat ketua bidang hikmah IMM kota Padang periode 2019-2020, dalam wawancaranya yakni dalam melakukan kegiatan atau pun menjalankan program kerja IMM terkendala tentang dana. Sebagaimana kita ketahui dalam organisasi tersebut, IMM hanya mempunyai dana dari iuran anggota. Selain mengajukan proposal untuk menambah anggaran 
dana. Namun hal tersebut menjadi hambatan bagi IMM untuk menjalankan program kerja. Ditambah lagi sarana dan prasarana yang ada masih kurang. Dengan kondisi mayoritas anggota adalah mahasiswa UIN jadi kadang mengadakan rapat atau diskusi hanya di kampus saja.

\section{b. Keterbatasan narasumber}

Narasumber penting untuk menjalankan program kerja yang dilakukan dengan mengadakan seminar atau mengadakan diskusi mengenai isu-isu politik. Dalam organisasi IMM ini ada beberapa kendala menganai narasumber yang akan di undang untuk mengisi acara seminar. Kendala dalam melakukan kegiatan yang berhubungan dengan narasumber adalah waktu yang terbatas dan terkadang narasumber yang kita undang tidak bias memenuhi undangan disebabkan beberapa hal yang terkesan mendadak. Selain itu pun berhubungan dengan dana, ada beberapa narasumber yang tidak bersedia karena sarana atau prasarana yang tidak sesuai.

c. Keterbatasan sumber daya manusia atau pengelola

Hambatan lain yaitu tentang pengelolaan dan waktu pelaksanaan. IMM adalah organisasi yang tidak memiliki penghasilan bagi anggota namun dituntut untuk aktif. Beberapa anggota mengabaikan kewajibannya sebagai mahasiswa. Meskipun hal tersebut sebenarnya lumrah karena ada ketika jadwal kegiatan terkadang serentak dengan jadwal kuliah. Dengan demikian kader IMM harus dapat membagi waktu dan mengutamakan prioritas tanpa merugikan pihak lain. Kemudian tidak seluruh kader dapat berpartisipasi sebab jadwal ujian antara perguruan tinggi yang berbeda-beda.

\section{KESIMPULAN}

Peran organisasi kepemudaan Ikatan Mahasiswa Muhammadiyah (IMM) dalam melakukan pendidikan politik bagi pemuda, yang terdapat dalam bidang hikmah, politik, dan kebijakan publik dilakukan melalui program kerja diantaranya membantu pemerintah daerah dan mensosialisasikan politik khususnya mengenai isu-isu krusial, melakukan pelatihan edukasi politik terhadap kader IMM, dan mendukung dalam kontribusi pemikiran dan kontribusi dalam membranding kader IMM untuk maju dalam internal kampus. Hambatan peran organisasi kepemudaan IMM dalam melakukan pendidikan politik bagi pemuda yakni karena keterbatasan anggaran, keterbatasan narasumber, keterbatasan sumber daya manusia atau pengelola.

\section{DAFTAR PUSTAKA}

Budiarjo, Miriam, 2008. Dasar-dasar Ilmu Politik. Jakarta: PT Gramedia Pustaka Utama

Cahyani, Riya. 2016. "Peran angkatan Muda Muhammadiyah (AMM) Prawirodirjan dalam Upaya Mengembangkan Karakter Pemuda di wilayah Prawirodirjan, Gondomanan, Yogyakarta".Jurnal Elektronik Mahasiswa PLS(Volume 5, No 5).

Hutami, Gartiria and Chariri, Anis (2011) pengaruh konflik peran dan ambiguitas peran terhadap komitmen independensi auditor internal pemerintah daerah. Undergraduate thesis, Universitas Diponegoro 
Junitasari, Dwi Erawati. Maya, Mustika Kartika Sari. 2017. "Peran Ikatan Pelajar Muhammadiyah (IPM) dalam Pendidikan Politik di SMA Muhammadiyah 2 Surabaya". Jurnal Kajian Moral dan Kewarganegaraan(Volume 5, No 1)

Munir Mulkhan, Abdul. 1990. Pemikiran Kyai Haji Ahmad Dahlan dan Muhammadiyah dalam Perspektif Perubahan Sosial. Jakarta: Bumi Aksara

Noor Affandi, Firmansyah. 2015.“Pelaksanaan Pendidikan Politik Dalam Meningkatkan Partisipasi Politik Generasi Muda". Skripsi. Jurusan Ilmu Pemerintahan, FISIP, Universitas Muhammadiyah Malang

Sugiyono. 2017. Metode penelitian Kombinasi (Mixed Methods). Bandung: Alfabeta.

Tanfidz Muktamar IMM XVIII

Tanzil, fey-fey. 2015. Partisipasi pemuda pancasila dalam membantu pemerintah menjaga stabilitas social di kota Samarinda. Portal karya ilmiah. Fakultas ilmu social dan ilmu politik Universitas Mulawarman.

Undang-UndangRepublik Indonesia Nomor 40 Tahun 2009 Tentang Kepemudaan 